No 4069

Studia nad Autorytaryzmem i Totalitaryzmem 43, nr 2

Wrocław 2021

https://doi.org/10.19195/2300-7249.43.2.22

\author{
MICHAŁ RADUŁA \\ ORCID: 0000-0002-9527-966X \\ Uniwersytet Wrocławski \\ michal.radula@uwr.edu.pl
}

\title{
Podmioty służby zdrowia w PRL
}

Słowa kluczowe: służba zdrowia, Polska Rzeczpospolita Ludowa, zespoły opieki zdrowotnej, świadczenia opieki zdrowotnej finansowane ze środków publicznych.

\section{HEALTHCARE PROVIDERS IN POLISH PEOPLE'S REPUBLIC}

\section{Abstract}

In the current legislation, the public tasks related with healthcare are performed by the healthcare entities. In the totalitarian and authoritarian Polish People's Republic, the healthcare was functioning as a communist health and social welfare system. It was a centralised structure with the main role of the Ministry of Health. The article shows the most important regulations in the field of healthcare system entities in the Polish People's Republic.

Keywords: healthcare, Polish People's Republic, healthcare facilities, healthcare services financed from public funds.

\section{Podmioty służby zdrowia w Konstytucji i ustawodawstwie PRL}

Konstytucja Polskiej Rzeczypospolitej Ludowej z dnia 22 lipca 1952 roku, w art. 60 ust. 1 stanowiła, że „Obywatele mają prawo do ochrony zdrowia oraz do pomocy w razie choroby lub niezdolności do pracy". Ponadto art. 60 ust. 2 rozwijał, że

szerszemu urzeczywistnieniu tego prawa [do ochrony zdrowia - M.R] służą:

1. rozwój ubezpieczenia społecznego robotników i pracowników umysłowych na wypadek choroby, starości i niezdolności do pracy oraz rozbudowa różnych form pomocy społecznej, 
2. rozwój organizowanej przez państwo ochrony zdrowia ludności, rozbudowa urządzeń sanitarnych i podnoszenie stanu zdrowotnego miast i wsi, stałe polepszanie warunków bezpieczeństwa, ochrony i higieny pracy, szeroka akcja zapobiegania chorobom i ich zwalczania, coraz szarsze udostępnianie bezpłatnej pomocy lekarskiej, rozbudowa szpitali, sanatoriów, ambulatoriów, wiejskich ośrodków zdrowia, opieka nad inwalidami ${ }^{1}$.

Zaznaczenia wymaga, że do 1948 roku system ochrony zdrowia w PRL funkcjonował na podstawie ustawodawstwa II Rzeczypospolitej ${ }^{2}$. W wymiarze ubezpieczeniowym była to ustawa $\mathrm{z}$ dnia 28 marca 1933 roku o ubezpieczeniu społecznym ${ }^{3}$, a jeśli chodzi o system opieki zdrowotnej — ustawa z dnia 15 czerwca 1939 roku o publicznej służbie zdrowia ${ }^{4}$. Dopiero w 1948 roku uchwalono ustawę o zakładach społecznych i planowej gospodarce w służbie zdrowia, który to akt normatywny wprowadzał socjalistyczne mechanizmy do opieki zdrowotnej w kraju ${ }^{5}$.

Jako podstawowe podmioty służby zdrowia w PRL ustanowiono ,zakłady społeczne służby zdrowia”, do której to kategorii zakwalifikowano:

1. zakłady lecznicze utrzymywane przez państwo, instytucje państwowe, związki samorządu terytorialnego, a także przez instytucje ubezpieczeń społecznych;

2. szpitale posiadające prawo publiczności na podstawie art. 6 i 78 rozporządzenia Prezydenta Rzeczypospolitej z dnia 22 marca 1928 roku o zakładach leczniczych ${ }^{6}$;

1 Art. 60 Konstytucji Rzeczypospolitej Ludowej z dnia 22 lipca 1952 roku (Dz.U. z 1952 r. $\mathrm{Nr} 33$, poz. 232 ze zm.).

2 O kształtowaniu się polskiego systemu ochrony zdrowia w XX wieku szerzej zob. J. Nosko, Zdrowie publiczne $w$ Europie $i w$ Polsce. Ksztaltowanie się rozwiazań modelowych (szkic historyczny), [w:] Zdrowie publiczne. Wybrane zagadnienia, red. J.A. Indulski, Z. Jethon, L. Dawydzik, Łódź 2000, s. 43-48; a także Z. Jethon, Rozwój zdrowia publicznego na przestrzeni wieków w Europie i Polsce, [w:] Zdrowie publiczne - wybrane zagadnienia, red. D. Wałęga-Szych, Legnica 2015, s. 15-18.

3 Dz.U. z 1933 r. Nr 51, poz. 396 ze zm.

4 Dz.U. z 1939 r. Nr 54, poz. 342 ze zm.

5 Ustawa z dnia 28 października 1948 roku o zakładach społecznych i planowej gospodarce w służbie zdrowia (Dz.U. z 1948 r. Nr 55, poz. 434 ze zm.) (dalej: ustawa o zakładach społecznych); zob. też o sytuacji społeczno-ekonomicznej w Polsce po II wojnie światowej w kontekście zdrowia publicznego E. Więckowska, Migracje ludności w Polsce po zakończeniu I wojny światowej $w$ świetle międzynarodowych konwencji zapobiegania chorobom zakaźnym, [w:] Zdrowie $i$ choroba jako problem społeczny. Medycyna w kontekście działań państwa, red. B. Płonka-Syroka, T. Srogosz, Wrocław 2005 s. 116; M. Sygit, Zdrowie publiczne, Warszawa 2010, s. 34; M. Posłuszna, Zdrowie społeczeństwa polskiego w środowisku wiejskim w II Rzeczpospolitej, [w:] Zdrowie i edukacja prozdrowotna społeczeństwa polskiego na przestrzeni XIX i XX wieku. Wybrane aspekty, red. M. Posłuszna, Poznań 2007, s. 91; J. Sobczak, Kasy chorych w Wielkopolsce w początkach II Rzeczypospolitej, [w:] Polska polityka zdrowotna a akcesja Rzeczpospolitej do Unii Europejskiej, red.T. Maksymiuk, J. Skrzypczak, Poznań 2006, s. 204-206; J. Leowski, Polityka zdrowotna a zdrowie publiczne. Ochrona zdrowia w gospodarce rynkowej, Warszawa 2009, s. 162.

${ }^{6}$ Dz.U. z 1928 r. Nr 38, poz. 382 ze zm. 
3. zaliczone przez Ministra Zdrowia do tej kategorii zakłady lecznicze utrzymywane przez fundacje, kongregacje, związki i stowarzyszenia religijne oraz nienastawione na zysk zakłady lecznicze innych osób prawnych;

\section{4. apteki ${ }^{7}$.}

Ustawa o zakładach społecznych dotyczyła państwowych zakładów leczniczych o charakterze specjalistycznym (zakładanych i utrzymywanych przez państwo). Podmioty te zabezpieczać miały zapotrzebowanie zdrowotne na obszarze co najmniej jednego województwa, w szczególności w zakresie onkologii, sanatoriów dla osób chorych na gruźlicę, szpitali psychiatrycznych oraz sanatoriów dla osób nerwowo chorych. Drugą kategorią państwowych zakładów leczniczych były szpitale wojewódzkie, a więc szpitale specjalistyczne mające swą siedzibę w miastach wojewódzkich lub w większych miastach, których celem było udzielanie pomocy specjalistycznej pacjentom na terenie całego województwa lub znacznej jego części. Ponadto zadaniem szpitali wojewódzkich było także dokształcanie oraz szkolenie lekarzy i innego personelu medycznego. Trzecim rodzajem państwowego zakładu leczniczego ustanowionego w treści ustawy o zakładach społecznych były szpitale kliniczne, zatem szpitale, których wszystkie lub większość oddziałów przeznaczone były na cele klinik szkół wyższych. Szpitale kliniczne realizowały jednocześnie zadania szpitali wojewódzkich ${ }^{8}$.

Jeśli chodzi o samorządowe zakłady lecznicze, obowiązek ich zakładania i utrzymywania spoczywał na powiatowych związkach samorządu terytorialnego. Jako zakłady lecznicze samorządu terytorialnego ustanowiono okręgowe ośrodki zdrowia, powiatowe ośrodki zdrowia oraz szpitale powiatowe. Ponadto analogiczny obowiązek spoczywał na miastach wydzielonych z powiatowego związku samorządu terytorialnego. Rada Państwa na wniosek ministra zdrowia zgłoszony w porozumieniu z ministrem administracji publicznej lub ministrem Ziem Odzyskanych posiadała kompetencje do modyfikacji wyżej wskazanych obowiązków, poprzez ich intensyfikację lub odjęcie ${ }^{9}$.

Oprócz państwowych oraz samorządowych zakładów leczniczych, jako społeczne zakłady służby zdrowia funkcjonowały także zakłady instytucji ubezpieczeń społecznych. Ówczesny kształt ustawodawstwa regulował, że celem wykonania obowiązków dotyczących udzielania pomocy leczniczej osobom ubezpieczonym, a także innym osobom uprawnionym, instytucje ubezpieczeń społecznych korzystają w szczególności z ośrodków zdrowia, szpitali oraz innych urządzeń leczniczych ${ }^{10}$. Instytucje ubezpieczeń społecznych posiadały również kompetencje do tworzenia nowych zakładów leczniczych samodzielnie, a także wspólnie

${ }^{7}$ Art. 1 ustawy o zakładach społecznych.

${ }^{8}$ Zob. art. 3-5 ustawy o zakładach społecznych; A. Zemke-Górecka, Status prawny samodzielnego publicznego zakładu opieki zdrowotnej i jego prywatyzacja, Warszawa 2010, s. 29-35.

${ }^{9}$ Art. 6-8 ustawy o zakładach społecznych.

10 Art. 9 ust. 1 ustawy o zakładach społecznych. 
ze związkami samorządu terytorialnego, do tworzenia i prowadzenia zakładów i urządzeń leczniczych ${ }^{11}$.

Na mocy przepisów ustawy o zakładach społecznych Rada Ministrów posiadała kompetencje do objęcia — w drodze uchwały — zakładu społecznego służby zdrowia w zarząd państwowy lub na własność państwa, gdy utrzymywanie danego zakładu było kwalifikowane jako zadanie państwa. Podobnie w drodze uchwały Rada Ministrów mogła ustanowić przejęcie przez związek samorządu terytorialnego w zarząd lub na własność zakładu społecznego służby zdrowia. Przejęcie miało na celu zapewnienie prawidłowego funkcjonowania sieci zakładów społecznych służby zdrowia. Ponadto przejęcie było możliwe, gdy właściciel zakładu nie był w stanie utrzymać zakładu na odpowiednim, wymaganym poziomie ${ }^{12}$. W aktualnym kształcie ustawodawstwa brak analogicznej regulacji, natomiast pewnych podobieństw można upatrywać w treści przepisu art. 59 ustawy o działalności leczniczej ${ }^{13}$, regulującego kompetencje podmiotu tworzącego do likwidacji Samodzielnego Publicznego Zakładu Opieki Zdrowotnej.

Mówiąc o funkcjonowaniu strukturalnym zakładów społecznych służby zdrowia, warto podkreślić kwestię ich ulokowania. Kompetencje do ustalenia - w porozumieniu z właściwymi ministrami - planów rozmieszczenia (tak zwanych sieci) zakładów społecznych służby zdrowia, posiadał minister zdrowia. Natomiast nowe zakłady społeczne służby zdrowia mogły być tworzone jedynie w ramach planu rozmieszczenia ${ }^{14}$. Aktualnie obowiązująca ustawa o świadczeniach opieki zdrowotnej finansowanych ze środków publicznych również wprowadza rozwiązania dotyczące oceny potrzeb zdrowotnych. Bezpieczeństwo zdrowotne jednostek w kontekście zapewnienia dostępności do świadczeń opieki zdrowotnej, gwarantowane jest na podstawie regionalnych map potrzeb zdrowotnych. Mapy te sporządzane są dla obszaru województwa, z uwzględnieniem specyfiki zapotrzebowania zdrowotnego społeczności lokalnych. Organem kompetentnym do sporządzenia regionalnej mapy potrzeb zdrowotnych jest właściwy wojewoda, który realizuje to zadanie w porozumieniu z Wojewódzką Radą do spraw Potrzeb Zdrowotnych. Narodowy Instytut Zdrowia Publicznego — Państwowy Zakład Higieny sporządza, na podstawie regionalnych map potrzeb zdrowotnych, Ogólnopolską Mapę Potrzeb Zdrowotnych. Zarówno mapa ogólnopolska, jak i mapy regionalne, zatwierdzane są przez ministra właściwego do spraw zdrowia ${ }^{15}$.

11 Art. 9 ust. 2 ustawy o zakładach społecznych.

12 Zob. art. 13 ustawy o zakładach społecznych.

13 Ustawa z dnia 15 kwietnia 2011 roku o działalności leczniczej, tekst jedn. z dnia 16 marca 2021 roku (Dz.U. z 2021 r. poz. 711); zob. T. Rytlewski, [w:] Ustawa o działalności leczniczej. Komentarz, red. F. Grzegorczyk, Warszawa 2013, s. 202-206.

14 Art. 15 ustawy o zakładach społecznych.

15 Szerzej zob. art. 95a ustawy z dnia 27 sierpnia 2004 roku o świadczeniach opieki zdrowotnej finansowanych ze środków publicznych, tekst jedn. z dnia 15 lipca 2020 roku (Dz.U. z 2020 r. poz. 1398 ze zm.); E. Fryźlewicz-Chrapisińska, [w:] Ustawa o świadczeniach opieki zdrowotnej fi- 


\section{Organizacja i funkcjonowanie podmiotów służby zdrowia na podstawie rozporządzeń ministra zdrowia i opieki społecznej}

Służba zdrowia w okresie PRL była strukturą ściśle scentralizowaną i hierarchiczną. Podstawy prawne funkcjonowania podmiotów służby zdrowia były w szerokim zakresie regulowane w treści rozporządzeń ministra zdrowia i opieki społecznej. Reformy były wprowadzane w latach $1967^{16}, 1973^{17}, 1975^{18}, 1982^{19}$ i $1989^{20}$, zaś jako mającą największe znaczenie wskazać należy reorganizację z 1973 roku, z uwagi na wprowadzenie do służby zdrowia zespołów opieki zdrowotnej, które miały istotny wpływ na rozwój służby zdrowia w PRL ${ }^{21}$.

W rozporządzeniu ministra zdrowia i opieki społecznej z dnia 20 lutego 1973 roku w sprawie organizacji zespołów opieki zdrowotnej, jako zakłady służby zdrowia realizujące opiekę zdrowotną uregulowano: zespoły opieki zdrowotnej (obszar powiatu), zespoły wojewódzkich przychodni, zespoły specjalistyczne oraz szpitale wojewódzkie (obszar województwa), a także jednostki organizacyjne akademii medycznych i instytutów naukowych (obszar obejmujący terytorium więcej niż jednego województwa). Za zgodą ministra zdrowia i opieki społecznej mogły być tworzone także zespoły przemysłowej służby zdrowia oraz opieki zdrowotnej dla szkół wyższych. System opieki zdrowotnej uzupełniały również inne podmioty, takie jak na przykład powiatowe, portowe i wojewódzkie stacje sanitarno-epidemiologiczne, wojewódzkie stacje krwiodawstwa oraz wojewódzkie stacje pogotowia ratunkowego. Zespoły opieki zdrowotnej realizowały zadania z zakresu udzielania miejscowej ludności podstawowej oraz specjalistycznej opieki zdrowotnej. Zespoły wojewódzkich przychodni wykonywały natomiast w szczególności zadania związane z udzielaniem ambulatoryjnych świadczeń specjalistycznych, które uzupełniały świadczenia udzielane przez zespoły opieki zdrowotnej. Ponadto do zakresu działania tych jednostek należało także udzielanie świadczeń

nansowanych ze środków publicznych. Komentarz, red. A. Pietraszewska-Macheta, Warszawa 2018, s. $665-666$.

16 Rozporządzenie Ministra Zdrowia i Opieki Społecznej z dnia 31 lipca 1967 roku w sprawie organizacji otwartej opieki zdrowotnej (Dz.U. z 1967 r. Nr 36, poz. 183).

17 Rozporządzenie Ministra Zdrowia i Opieki Społecznej z dnia 20 lutego 1973 roku w sprawie organizacji zespołów opieki zdrowotnej (Dz.U. z 1973 r. Nr 7, poz. 52).

18 Rozporządzenie Ministra Zdrowia i Opieki Społecznej z dnia 30 czerwca 1975 roku w sprawie organizacji i zadań zakładów opieki zdrowotnej (Dz.U. z 1975 r. Nr 25, poz. 134).

19 Rozporządzenie z dnia 19 maja 1982 roku w sprawie organizacji i zadań zakładów opieki zdrowotnej (Dz.U. z 1982 r. Nr 15, poz. 121).

20 Rozporządzenie Ministra Zdrowia i Opieki Społecznej z dnia 2 maja 1989 roku zmieniające rozporządzenie w sprawie organizacji i zadań zakładów opieki zdrowotnej (Dz.U. z 1989 r. Nr 28, poz. 152).

${ }^{21}$ K. Prętki, Przekształcenia systemu ochrony zdrowia w Polsce po II Wojnie Światowej, Poznań 2007, s. 55. 
konsultacyjnych oraz nadzór specjalistyczny. Zadania wojewódzkich zespołów specjalistycznych ogniskowały się wokół świadczenia opieki zdrowotnej o charakterze specjalistycznym $\mathrm{w}$ danej dziedzinie medycyny ${ }^{22}$. Natomiast szpitale wojewódzkie realizowały zadania w szczególności z zakresu:

1. sprawowania opieki stacjonarnej w dziedzinach uzupełniających opiekę zdrowotną specjalistyczną sprawowaną przez zespoły opieki zdrowotnej lub w przypadkach wymagających szczególnych warunków lub kwalifikacji zawodowych,

2. udzielanie specjalistycznych i konsultacyjnych świadczeń ambulatoryjnych, jeżeli w skład szpitala wchodzą poradnie specjalistyczne,

3. organizowanie i prowadzenie szkolenia i dokształcanie pracowników medycznych ${ }^{23}$.

Zakłady służby zdrowia kwalifikowane jako jednostki organizacyjne akademii medycznych i instytutów badawczych, które sprawowały opiekę zdrowotną na obszarze większym niż jedno województwo, wykonywały w szczególności zadania takie jak udzielanie wysoko kwalifikowanych świadczeń konsultacyjnych, udzielanie specjalistycznych świadczeń leczniczych, sprawowanie nadzoru specjalistycznego ${ }^{24}$.

\section{Wnioski}

Służba zdrowia w PRL wzorowana była na modelu radzieckim, charakteryzującym się przede wszystkim powszechnym dostępem do świadczeń zdrowotnych finansowanych z budżetu państwa oraz zatrudnieniem lekarzy na etatach państwowych ${ }^{25}$. Zadaniem podmiotów służby zdrowia w PRL było udzielanie świadczeń zdrowotnych, przy zachowaniu ich ciągłości oraz dostępności. Realizacja tych zadań przebiegała jednak niesprawnie, a to z uwagi na duży — w kontekście strukturalnym systemu — stopień centralizacji decyzji, niską samodzielność decyzyjną podmiotów służby zdrowia, brak postępowania zgodnie z rachunkiem ekonomicznym odnośnie do środków finansowych przekazywanych danym podmiotom (nadmierne zadłużanie się poszczególnych jednostek, a w efekcie całego systemu). Jako pozytywne aspekty służby zdrowia w okresie PRL wskazać natomiast można upowszechnienie opieki zdrowotnej w kraju, a także odbudowę podmiotów ochrony zdrowia po ustąpieniu działań wojennych ${ }^{26}$.

$22 \S 1,2,6,8,9,10$ rozporządzenia w sprawie organizacji zespołów opieki zdrowotnej.

23 Działalność szpitala wojewódzkiego obejmować mogła jedną dziedzinę medycyny lub różne specjalności — $§ 11$ rozporządzenia w sprawie organizacji zespołów opieki zdrowotnej.

$24 \S 13$ ust. 1 rozporządzenia w sprawie organizacji zespołów opieki zdrowotnej.

25 E.P. Wąsiewicz, Obraz polskiej reformy zdrowia, [w:] Ekonomiczno-organizacyjne problemy restrukturyzacji stużby zdrowia. Materiaty z konferencji naukowej zorganizowanej 23 listopada 1999 r. w Wyższej Szkole Marketingu i Zarządzania w Lesznie, red. T. Mendel, W. Kapczyński, Leszno 1999, s. 45, za: K. Prętki, op. cit., s. 58.

${ }^{26}$ K. Prętki, op. cit., s. 58 i 64. 
Podmioty służby zdrowia w okresie PRL funkcjonowały w radykalnie odmiennym od aktualnego kształtu prawodawstwa otoczeniu prawnym. Służba zdrowia stanowiła scentralizowaną administrację specjalną, z rozległymi kompetencjami ministra zdrowia. Finansowana była bezpośrednio z budżetu państwa, zakłady opieki zdrowotnej wykonywały swe zadania jako państwowe jednostki organizacyjne, w których zatrudnieni byli lekarze, kwalifikowani jako funkcjonariusze publiczni (dodać jeszcze można państwowy monopol dotyczący zaopatrzenia w leki i materiały medyczne) ${ }^{27}$. W aktualnym stanie prawnym zadania $\mathrm{z}$ zakresu ochrony zdrowia wykonują podmioty będące jednostkami systemu ochrony zdrowia, w ramach którego celem nadrzędnym jest realizacja publicznego prawa podmiotowego pacjentów — prawa do ochrony zdrowia (art. 68 ust. 1 Konstytucji Rzeczypospolitej Polskiej) ${ }^{28}$.

\section{Bibliografia}

Dercz M., Rek T., Ustawa o działalności leczniczej. Komentarz, Warszawa 2019.

Ekonomiczno-organizacyjne problemy restrukturyzacji stużby zdrowia. Materiały z konferencji naukowej zorganizowanej 23 listopada 1999 r. w Wyższej Szkole Marketingu i Zarzadzania w Lesznie, red. T. Mendel, W. Kapczyński, Leszno 1999.

Leowski J., Polityka zdrowotna a zdrowie publiczne. Ochrona zdrowia w gospodarce rynkowej, Warszawa 2009.

Polska polityka zdrowotna a akcesja Rzeczpospolitej do Unii Europejskiej, red. T. Maksymiuk, J. Skrzypczak, Poznań 2006.

Prętki K., Przeksztatcenia systemu ochrony zdrowia w Polsce po II Wojnie Światowej, Poznań 2007. Realizacja i ochrona konstytucyjnych wolności i praw jednostki w polskim porzadku prawnym, red. M. Jabłoński, Wrocław 2014.

Sygit M., Zdrowie publiczne, Warszawa 2010.

Ustawa o działalności leczniczej. Komentarz, red. F. Grzegorczyk, Warszawa 2013.

Ustawa o świadczeniach opieki zdrowotnej finansowanych ze środków publicznych. Komentarz, red. A. Pietraszewska-Macheta, Warszawa 2018.

Zdrowie i choroba jako problem społeczny. Medycyna w kontekście działań państwa, red. B. Płonka-Syroka, T. Srogosz, Wrocław 2005.

Zdrowie i edukacja prozdrowotna społeczeństwa polskiego na przestrzeni XIX i XX wieku. Wybrane aspekty, red. M. Posłuszna, Poznań 2007.

Zdrowie publiczne. Wybrane zagadnienia, red. J.A. Indulski, Z. Jethon, L. Dawydzik, Łódź 2000.

Zdrowie publiczne - wybrane zagadnienia, red. D. Wałęga-Szych, Legnica 2015.

Zemke-Górecka A., Status prawny samodzielnego publicznego zakładu opieki zdrowotnej i jego prywatyzacja, Warszawa 2010.

27 M. Dercz, [w:] M. Dercz, T. Rek, Ustawa o działalności leczniczej. Komentarz, Warszawa 2019, s. 44.

28 Zob. w szczególności Wyrok Trybunału Konstytucyjnego z dnia 7 stycznia 2004 roku (K 14/03); S. Jarosz-Żukowska, Prawo do ochrony zdrowia i dostępu do świadczeń opieki zdrowotnej, [w:] Realizacja i ochrona konstytucyjnych wolności i praw jednostki w polskim porządku prawnym, red. M. Jabłoński, Wrocław 2014, s. 659-689. 